\title{
THE ANALYSIS OF QUALITY MANAGEMENT TOOLS USED FOR IMPROVING THE PRODUCTION PROCESS BASED ON A CHOSEN FOUNDRY
}

\begin{abstract}
Summary: The article presents the analysis of quality management tools, such as the Ishikawa diagram and the Pareto-Lorenz diagram for flaw structure assessment of pulleys founded in the enterprise that is being surveyed. The conducted research allowed to identify the most significant inconsistencies that appear in pulleys. The analysis helped to diagnose their causes, which gives the basis for proposing appropriate corrective actions. The defect structure of the process has been presented using the ParetoLorenz diagram. In order to recognize the reasons of identified incompatibilities, the Ishikawa cause-andeffect diagram has been applied. Moreover, the article also includes a number of recommendations that are aimed at improving the entire process of pulleys production in this company.
\end{abstract}

Keywords: quality management, quality tools, Pareto-Lorenz diagram, The Ishikawa diagram,

\section{Introduction}

The problem of the quality of manufactured goods is considered to be one of the most crucial issues raised in connection with enterprise management. It is generally known that quality management and company supervising should be carried out in a systematic and clear way. Quality management is the undertaking of planned and coordinated activities directed at improving the effectiveness and flexibility of the company, which are aimed at meeting client's needs and expectations. The most important reasons can be identified through the use of quality management tools. The usage of such tools for the purpose of identifying the most essential causes of defects of goods on the example of pulleys production process has been presented in the further part of this article.

\section{Quality management}

The quality management system should be defined as a whole that is organizationally separated in the enterprise management system. It is a constituent of the quality management system along with a management system expressed in qualitative terms [1].

R.W. Griffin introduced a management approach that is composed of a number of operations, which include [2]:

- organizing,

- planning,

${ }^{1} \mathrm{PhD}$ student, Czestochowa University of Technology, andrew.rusecki@gmail.com 
- leading (motivating),

- controlling.

The activities that have been enumerated are directed at human, financial and informational (databases) resources, and are performed with the initiative of achieving the objectives developed by a given organization in a smooth and efficient way[3].

In quality management, the entirety of management agreements reached is associated with processes, resources and formative units. Decisions that are made concordantly have an enormous influence on quality creation. Quality management is the management of all processes and resources [4].

\section{Traditional quality management tools}

The Quality management processes in enterprises are subject to continuous monitoring of the production process and services. They are used for collecting and processing data that are based on quality aspects. Moreover, they allow to inspect and identify processes during production, design, control and assembly phases. The most common traditional quality management tools include [5]:

- the Pareto-Lorenz diagram,

- the Ishikawa diagram,

- bar graphs (histograms),

- correlation diagrams,

- control sheets,

- block diagrams,

- control cards.

The Pareto diagram (the ABC method) states that $20-30 \%$ of causes prompt 70 $80 \%$ of the effects. The Italian economist Vilfredo Pareto was the first one to discover and describe this issue [6]. The method defines that $80 \%$ of problems in the production area result from the $20 \%$ of machines, materials or operators.

The Pareto-Lorenz diagram is created in accordance with the following guidelines [7]:

- collect data on the situation that is being examined,

- rank causes from the most to the least important,

- determine cumulative values of all causes, i.e. the percentage value in proportion to the general phenomenon,

- place the degree of value of causes and their percentage share on the vertical axis,

- place causes from the largest to the smallest value on the horizontal axis,

- prepare the Pareto diagram, i.e. draw bar charts for each of the determined causes. The bars are to be arranged from the largest to the smallest value, 
- draw the Lorenz curve by marking the points that correspond to cumulative values, and connect these points with a line that defines the impact of incompatibilities to the amount of their occurrence.

The last action that has to be taken, is to exclude or eliminate the impact of the most important causes, and to improve the situation that is being examined [8].

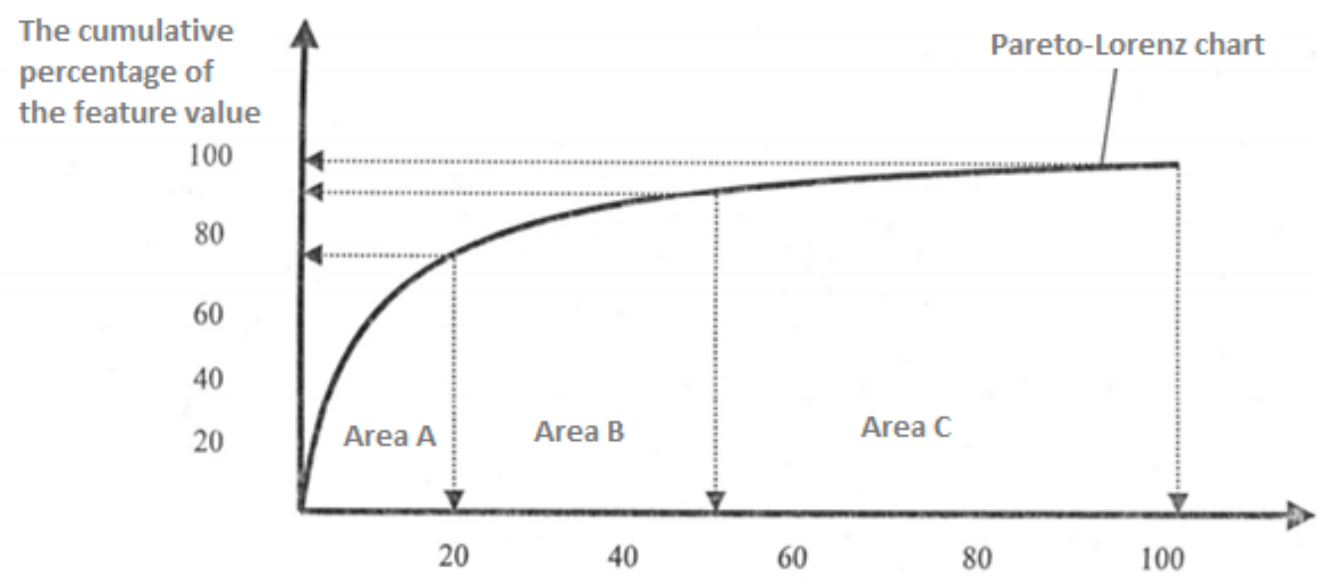

Fig. 1. An example of a Pareto-Lorenz diagram

Source: [10]

Figure 1 above presents the relation between the Pareto-Lorenz method and the $\mathrm{ABC}$ method. The $\mathrm{ABC}$ areas have been marked on the chart. Category $\mathrm{A}$ is about $20 \%$, category B - about $30 \%$ and category C is about 50\% [9]. The Pareto analysis makes it easier to find the $20 \%$ of causes that make the $80 \%$ of loss.

Three areas can be distinguished in the Pareto-Lorenz diagram [10]:

- area $\mathrm{A}$ - stops in this group have the most significant impact on the course or functioning of the process, liquidation or reduction of these standstills must be a priority,

- $\quad$ area B - it includes standstills, which should be eliminated in the second place, they have a smaller impact on the functioning of the process,

- area $\mathrm{C}$ - a group of standstills of low level of significance.

The Ishikawa diagram resembles a fish bone in shape (Figure 2). Groups of causes that affect a specific problem can be easily identified thanks to the Ishikawa cause-and-effect diagram. These groups are particularly helpful in identification, and include [11]:

- $5 \mathrm{M}$ (manpower, machinery, materials, methods, management),

- $5 \mathrm{M}+1 \mathrm{E}(5 \mathrm{M}+$ environment $)$, 
- $7 \mathrm{M}(5 \mathrm{M}+1 \mathrm{E}+$ measurement $)$,

- $8 \mathrm{M}(7 \mathrm{M}+$ money) [12].

A number of aspects have to be considered and realized when creating the Ishikawa diagram, thus it is important to [13]:

- determine contradictions and non-conformities,

- determine root causes,

- determine detailed causes that are associated with root causes,

- $\quad$ determine the most important factor (critical factor). The intermediate causes (i.e. detailed) are connected with root causes and create their extensions.

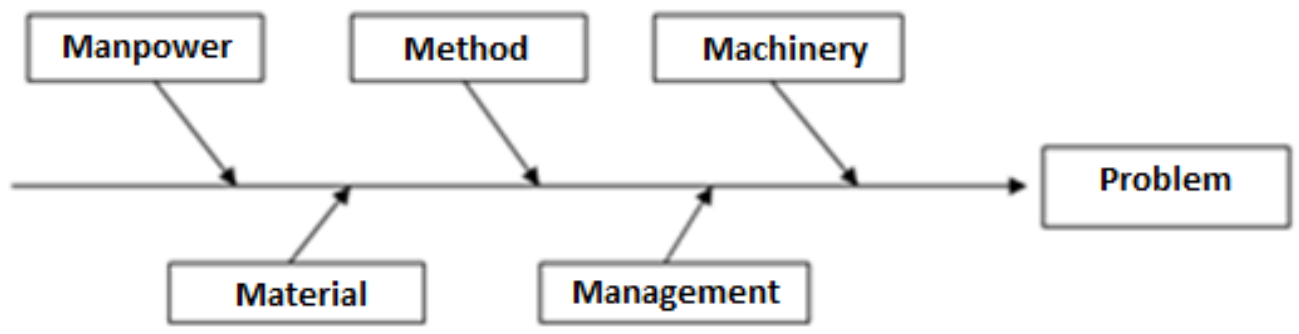

Fig. 2. Ishikawa cause-and-effect diagram

Source: [11]

The Ishikawa cause-and-effect diagram can be applied not only during the production process, but also when designing or preparing the manufacturing process.

\section{The profile of the examined object}

On The analyzed object is a pulley, which is the most important element of the belt drive. It is made of cast iron and then machined. Both active and passive pulleys can be distinguished. The pulley is superimposed on a shaft that drives the machine or is driven by it. In addition to that, it is made of two main elements: the rim and the hub. 


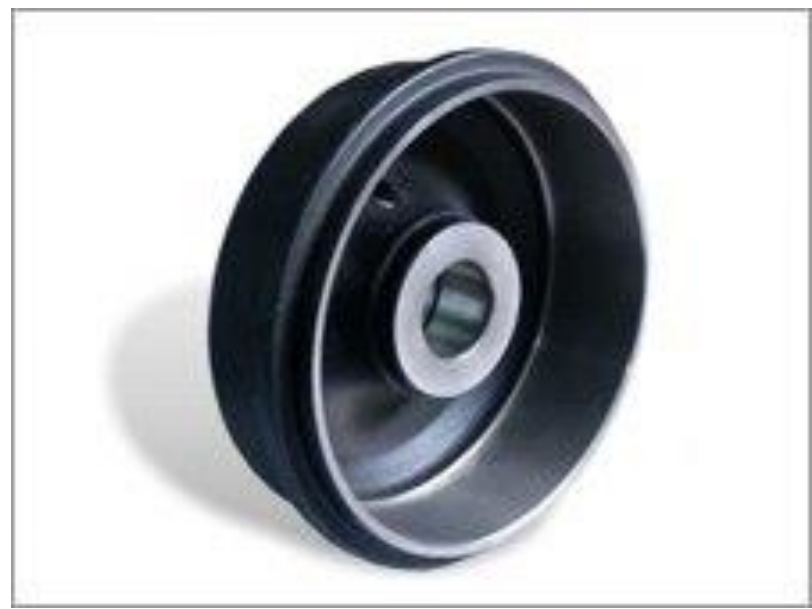

Fig. 3. An example of a pulley

Source: website of the company $X$

The pulley is the most important element of the belt drive. A belt is placed on the pulley. Both active and passive pulleys can be distinguished, and depending on this fact the pulley is placed either on the active or passive shaft. Pulleys can be divided into:

- smooth pulleys - adapted for the assembly of flat belts,

- pulleys with single or multiple grooves - adapted for the assembly of transmission belts (fan belts),

- $\quad$ pulleys with grooves across the circumference - adapted for the assembly of toothed belts.

A multi-groove pulley has been examined in the analysis. Pulleys with grooves are used to operate transmission belts that drives systems or mechanisms. Pulleys are cast and later machined. Cast iron used for pulleys is characterized by its durability and corrosion resistance.

It is particularly important to finish the surface of the pulley in places where it connects to the belt. A properly selected pulley eliminates vibrations and prevents their transfer on the drive, which would cause the occurrence of unwanted vibrations of the entire system.

\section{Identification of the causes of non-conformities through the use of the Ishikawa diagram}

In the company that is being studied, the application of the Ishikawa diagram allowed to identify the causes of non-conformities that result from damaged multi- 
groove surface of a pulley. The research and analysis have been conducted over a period of one week. People involved in this process included department managers, manual workers and quality controllers. Their prime task was to identify areas that generate the causes of the occurrence of non-conformities. The ground of manufacturing process, as well as the involvement of employees in the analyzed organization have been scrutinized and studied. The Ishikawa diagram for the damaged multi-groove surface of a pulley has been presented below (Figure 4).

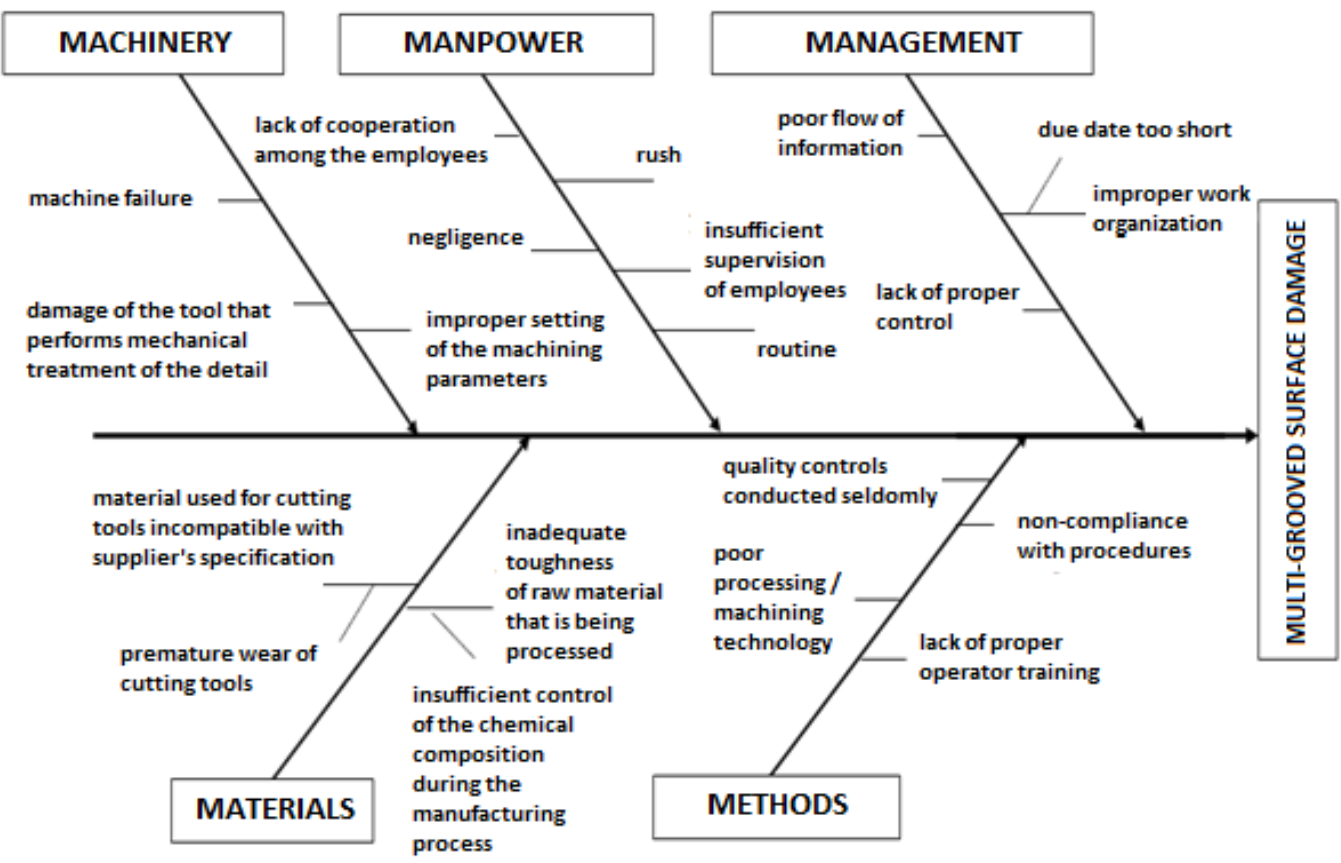

Fig. 4. The Ishikawa diagram for the damaged multi-groove surface of a pulley

Source: own study based on the data from company $X$

The analysis conducted through the use of the cause-and-effect diagram discovered most of the non-conformities in manpower and methods categories. The prime factor that causes damage of the multi-groove surface of the pulley in the category of manpower is primarily inaccurate and insufficient supervision of employees. Moreover, the source of failures and glitches in this category can also be the lack of cooperation among employees. When it comes to the category of methods, the analysis allowed to detect a number of issues that result in the damage of the multi-groove surface of the pulley. These include: quality controls conducted not often enough, procedures not being obeyed, poor and unfinished machining technology and lack of operator training. In the case of materials category, the main factor that affects 
the emergence of non-conformities is inadequate toughness of raw material that is being processed and materials used for cutting tools that are inconsistent or incompatible with supplier's specification. It resulted in premature wear of the material used on the tool. Inadequate flow of information caused by the lack of cooperation between departments in the company, lack of proper quality control, and work organization ordered improperly constitute the group of causes in the management category. A major reason that leads to the production of a flawed and incompatible product detected in subsequent category, i.e. machinery, is the failure of the machine. Machine failure is a constituent of many factors which include, among others, poor technical condition and the lack of proper maintenance of the device. Moreover, the damage of the tool that performs mechanical treatment of the detail and improper setting of the machining parameters can also be distinguished in this category. The analysis of the reasons that cause damage of the multi-groove surface of a pulley contributes to the elimination of errors that appear in each of the category presented. It can be concluded that the company should improve and modify the manpower category in the first place. The elimination of errors will undoubtedly have a positive impact on the efficiency of the company's services and the quality of the product and, as a result, on customer satisfaction.

\section{A quantitative approach to the problem of quality based on the Pareto- Lorenz diagram}

The Pareto-Lorenz diagram is a traditional tool applied to identify the most serious causes of incompatibilities that may occur during the manufacturing process of a pulley. With the occurrence of incompatibilities, the quality level of products decreases. The Pareto-Lorenz chart is based on the 20/80 rule, according to which relatively $20 \%$ of causes prompt $80 \%$ of the effects.

Table 1 below contains six incompatibilities that have been detected during the manufacturing process of a pulley, ranked by the frequency of their occurrence. It also presents information regarding the percentage share, as well as the cumulative percentage share and the cumulative amount of incompatibilities. 
Table 1. Incompatibilities detected during the pulley production process gathered in an organized way

\begin{tabular}{|c|c|c|c|c|}
\hline $\begin{array}{l}\overline{0} \\
\text { है } \\
\text { 苛 }\end{array}$ & 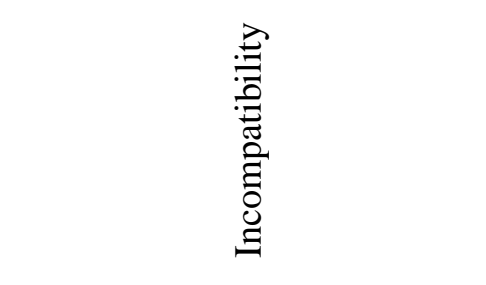 & 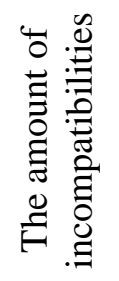 & 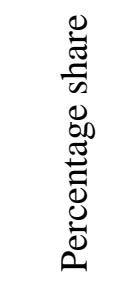 & 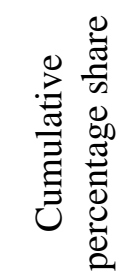 \\
\hline N4 & $\begin{array}{l}\text { Multi-groove surface damage } \\
\text { due to cutting tool damage }\end{array}$ & 76 & $60.8 \%$ & $60.8 \%$ \\
\hline N1 & $\begin{array}{l}\text { Porosity on the surface after } \\
\text { the mechanical treatment }\end{array}$ & 19 & $15.2 \%$ & $77 \%$ \\
\hline N3 & $\begin{array}{c}\text { Dimensional incompatibility } \\
\text { of the detail }\end{array}$ & 15 & $12 \%$ & $88 \%$ \\
\hline N5 & $\begin{array}{l}\text { Multi-groove surface } \\
\text { mechanical damage due to a } \\
\text { non-centric grip of the detail } \\
\text { by the machine manipulator }\end{array}$ & 6 & $4.8 \%$ & $92.8 \%$ \\
\hline $\mathrm{N} 2$ & $\begin{array}{l}\text { Mechanical damage of the ring } \\
\text { on the inner diameter below } \\
\text { the hub caused by a non- } \\
\text { centric grip of the detail by the } \\
\text { machine manipulator }\end{array}$ & 6 & $4.8 \%$ & $97.6 \%$ \\
\hline N6 & $\begin{array}{c}\text { Non-centric machining } \\
\text { performance due to a } \\
\text { displacement of raw detail } \\
\text { intake position by the machine } \\
\text { manipulator }\end{array}$ & 3 & $2.4 \%$ & $100 \%$ \\
\hline & In total: & 125 & $100 \%$ & - \\
\hline
\end{tabular}

Source: own study based on the data from company X. 
The data and figures in Table 1 above are necessary for creating the ParetoLorenz chart (Figure 5).

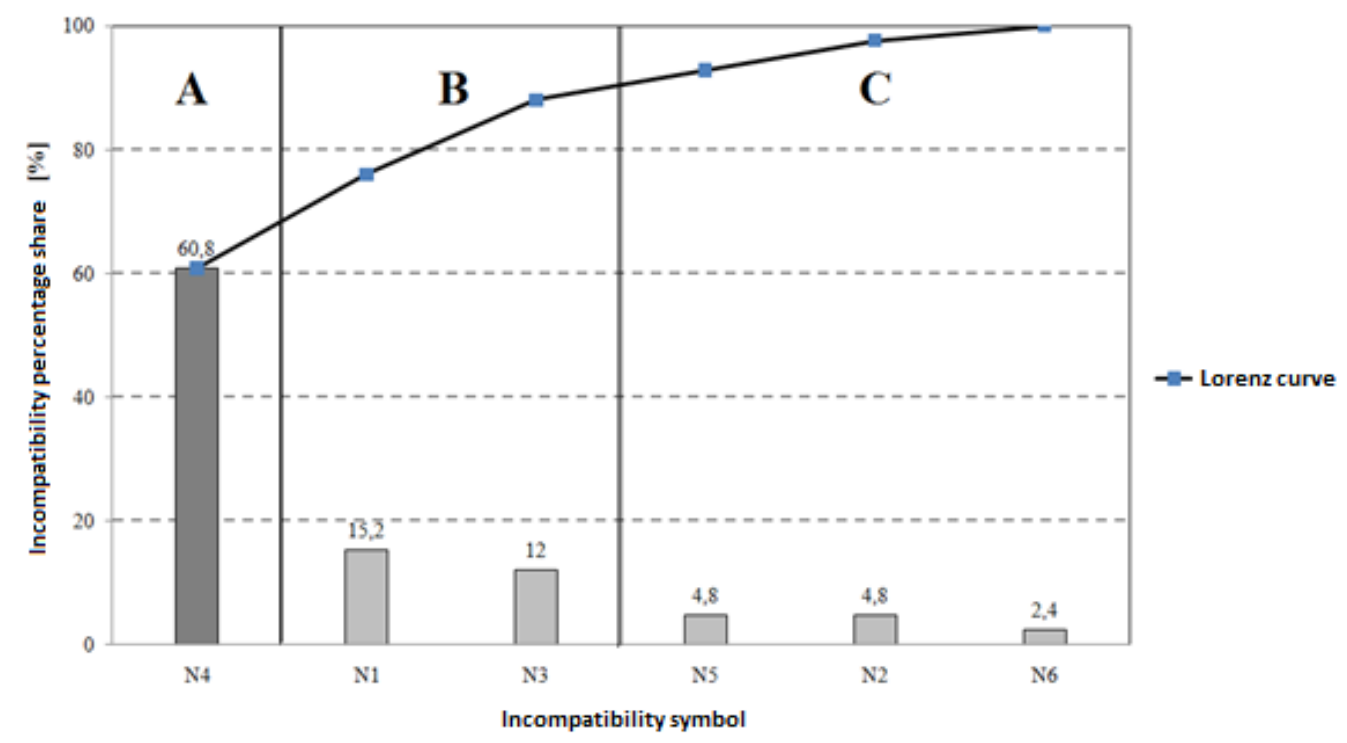

Fig. 5. Pareto-Lorenz chart for pulley manufacturing process

Source: own study based on the data from company $X$

Figure 5 above presents a curve that has been called the Lorenz curve and it determines the cumulative percentage share. When analyzing the Pareto-Lorenz chart, it can be concluded that there is one particularly important incompatibility (N4) that occurred in area A, i.e. multi-groove surface damage caused by cutting tool damage. It constitutes $20 \%$ of incompatibility types that occurred in the company and are responsible for $60.8 \%$ of incompatibilities that appeared in 125 manufactured details identified as defective. A complete elimination of this incompatibility may influence the decrease by more than $60 \%$ of the number of faulty products. Area B determines $30 \%$ of the causes of incompatibilities and generates $27.2 \%$ of all incompatibilities. This category consists of incompatibilities that are of moderate level of importance, i.e. $\mathrm{N} 1$ - porosity on the surface after the mechanical treatment, and N3 - dimensional incompatibility of the detail. In this case, a complete elimination of these incompatibilities may cause their removal by over $27 \%$. Three incompatibilities occurred in area $\mathrm{C}$, these include: N5 - multi-groove surface mechanical damage due to a non-centric grip of the detail by the machine manipulator, N2 - mechanical damage of the ring on the inner diameter below the hub caused by a non-centric grip of the detail by the machine manipulator, and N6 - non-centric machining performance due to a displacement of raw detail intake position by the machine 
manipulator. The elements that appear in this area are of the lowest level of importance. They account for $50 \%$ of incompatibilities and generate $12 \%$ of all finished products manufactured improperly.

Thanks to the Pareto-Lorenz analysis, reasons that have the greatest impact on the creation of improprieties when manufacturing pulleys could have been determined. The immediate action that must be taken by the company that is being studied should be the liquidation of specified incompatibilities. In order to improve the productivity of the pulley manufacturing process, company $\mathrm{X}$ should at the beginning of its operations eliminate causes of the occurrence of incompatibilities from group A, i.e. multi-groove surface damages due to cutting tool damage, which together generate almost $62 \%$ of all incompatibilities that occur in the entire manufacturing process. The above-mentioned non-conformity is mainly caused by producer's failure to deliver cutting tools with proper chemical composition, chosen intentionally for achieving high efficiency with high machining parameters. Producer's assurance to deliver appropriate tools and an accurate verification of chemical composition typical for such tools will greatly improve work efficiency and increase the repeatability of the production process. In order to reduce the number of mistakes and errors to a minimum, the company should modernize its machinery park. It is also recommended to increase visual control of castings in order to detect any material irregularities, such as blisters or gassings. Periodic inspection of the machinery and a more frequent supervision over employees will allow to streamline the process, taking into consideration the manpower factor. The Pareto-Lorenz diagram is not only an ideal tool for a quick problem analysis, but it also helps enterprises to develop actions that effectively prevent incompatibilities from occurring.

\section{Summary}

The quality management system is an important element of business management. It helps the company to determine and choose the right path of its development. Management systems ensure through the use of its tools and methods the opportunity to monitor processes in the organization constantly, and moreover help to respond to any disturbing symptoms. The application of various quality management tools and methods gives enterprises the opportunity to optimize the production process. The results of selected researches in the studied company concerned the application of various quality management tools, i.e. the Pareto-Lorenz chart and the Ishikawa diagram. Thanks to the analysis conducted by the use of these tools, it is easy to determine which errors are to be eliminated immediately in the first place. 
The Ishikawa diagram allowed to identify the reasons of incompatibilities associated with damaged multi-groove surface of pulleys that have been tested. When it comes to the Pareto-Lorenz diagram, six main discrepancies have been detected and analyzed. The research demonstrated that the most frequent cause of incompatibilities was prompted by multi-groove surface damage due to cutting tool damage. It constituted $20 \%$ of types of incompatibilities that occurred in the examined company, responsible for $60,8 \%$ of incompatibilities. 15000 pieces of pulleys produced over a period of one week went through the process of quality control. The control detected 125 of pulleys that were classified as non-qualitative and later used to carry out the Pareto-Lorenz analysis.

The conducted analysis regarding quality management issues shows that the choice of quality management tools in the enterprise depends on the type and character of problems the company strives to solve. It is worth to mention that tools and techniques play a major role in organizations focused on a continuous improvement, evaluation and monitoring of processes.

\section{Bibliography}

[1] Hamrol A.. Zarządzanie jakościa z przyktadami. Wydawnictwo Naukowe PWN, Warszawa 2002, pp.104.

[2] Griffin R.W. Podstawy zarządzania organizacjami. Wydawnictwo Naukowe PWN, Warszawa, 2005, pp.6.

[3] www.janek.uek.krakow.pl/ kzzo/1.4.pdf

[4] Hamrol A., Mantura W. Zarządzanie jakościa. Teoria i praktyka. Wydawnictwo Naukowe PWN, Warszawa 2002, pp. 92.

[5] Frąś J., Gołębiowski M., Bielawa A. Podstawy zarządzania jakościa w przedsiębiorstwie. Wydawnictwo Naukowe Uniwersytetu Szczecińskiego, Szczecin, 2006, pp. 58.

[6] Szczęśniak B., Zasadzień M., Wapienik Ł. „Zastosowanie analizy Pareto oraz diagramu Ishikawy do analizy przyczyn odrzutów w procesie produkcji silników elektrycznych," in Zeszyty naukowe politechniki śląskiej. Organizacja i zarządzanie, z. 63a , pp. 129.

[7] Ładoński W., Szołtysek K. Zarządzanie jakością. Wydawnictwo Uniwersytetu Ekonomicznego, Wrocław, 2008, pp. 102.

[8] Łunarski J. Zarządzanie jakością. Standardy i zasady. WNT, Warszawa, 2008, pp. 256.

[9] Wawak S. Podręcznik wdrażania ISO 9001:2000. Helion, Gliwice, 2007, pp. 139.

[10] Hibner M. „Wykorzystanie diagramu Pareto - Lorenza do analizy postojów/przestojów odstawy urobku," in Zeszyty Naukowe Państwowej Wyższej Szkoty Zawodowej im. Wielona w Legnicy, no 23, pp. 213, 2017.

[11]Poloczek Ł., Kiełbus A., Dybowski B. Zastosowanie diagramu przyczynowo-skutkowego Ishikawy $w$ diagnostyce wad odlewów. W: Innowacje w zarządzaniu i inżynierii produkcji, tom 2. Red. R. Knosali. Oficyna Wydawnictwa Polskiego Towarzystwa Zarządzania Produkcją. Opole 2017, pp. 370- 378. 
[12] Jagusiak-Kocik M., Knop K. Wykorzystanie wybranych narzędzi zarządzania jakością i metody FMEA w przedsiębiorstwie produkującym konstrukcje spawane dla maszyn," in Zeszyty Naukowe Quality. Production. Improvement, pp. 55, 2016.

[13] Wojciech Ł., Zawadzka K. „Wspomaganie diagnostyki wad odlewów narzędziami zarządzania jakościa," in Archiwum Technologii Maszyn i Automatyzacji, tom 28, nr 1, 2008, pp.92.

\section{ANALIZA NARZĘDZI ZARZĄDZANIA JAKOŚCIĄ STOSOWANYCH DO USPRAWNIENIA PROCESU PRODUKCYJNEGO W OPARCIU O WYBRANY ZAKLAD ODLEWNICZY}

Streszczenie: System zarządzania jakością jest jednym z najważniejszych czynników zarządzania przedsiębiorstwem. Pomaga firmie określić i wybrać właściwy kierunek jej rozwoju. Systemy zarządzania zapewniają za pomocą metod i narzędzi stałą możliwość monitorowania procesów przedsiębiorstwa, a ponadto umożliwiają szybką reakcję na wszelkie niepokojące symptomy. Różnorodność narzędzi i metod zarządzania jakością oraz ich zastosowanie w organizacji stwarza możliwości do optymalizacji procesów produkcji. Wyniki przeprowadzonych badań $\mathrm{w}$ badanej firmie dotyczyły zastosowania różnych narzędzi zarządzania jakością, tj. Wykresu Pareto-Lorenza oraz diagramu Ishikawy. Natomiast analiza przeprowadzona za pomocą wyżej wymienionych narzędzi umożliwia szybkie określenie, problemów które dana firma eliminować powinna w pierwszej kolejności.

Słowa kluczowe: narzędzia jakości, zarządzanie jakością, diagram Pareto-Lorenz, diagram Ishikawy

Date of sending the publication to the Editor: 26.05.2018

The date of the publication's acceptance by the Editorial Board: 03.07.2018 